\title{
Genetic diversity of eight wild populations of Pampus argenteus along the coast of China inferred from fifteen polymorphic microsatellite markers
}

\author{
Dandan Sun ${ }^{1}$, Yushuang Ge $e^{1}$, Qiqun Cheng ${ }^{1, *}{ }^{*}$
}

\begin{abstract}
East China Sea Fisheries Research Institute, Chinese Academy of Fishery Sciences, Key Laboratory of Oceanic and Polar Fisheries, Ministry of Agriculture and Rural Affairs, YangPu (Shanghai - China)

*Corresponding author: chengqq@ecsf.ac.cn
\end{abstract}

\begin{abstract}
Pampus argenteus (Perciformes: Stromateidae) is widely distributed along the coast of China, Indian Ocean, Arabian Gulf and North Sea. Due to overfishing and environmental degradation, its resources reduced year after year. Thus, new management strategies are urgently needed for the sustainable growth and utilization of this species. Characterization of the genetic variation of this fish species is essential for conserving the genetic resource and restraining the population decline. Therefore, it is necessary to have a clear understanding of the intraspecific genetic diversity and population structure of the species. In this study, we assess the genetic diversity and population structure of $P$. argenteus by using microsatellites. We genotyped $240 P$. argenteus individuals from eight wild populations collected from Shidao (SD), Lianyungang (LYG), Lvsi (LS), Zhoushan (ZS), Dongtou (DT), Xiapu (XP), Haikou (HK), and Beibuwan (BBW) along the coast of China using fifteen polymorphic microsatellites. A total of 139 alleles were determined at 15 loci across the eight populations, and a relatively high level of genetic diversity was observed, with observed heterozygosity (Ho) and expected heterozygosity (He) ranging from 0.100 to 1.000 , and from 0.669 to 0.934 per locus-location combination, respectively. LS had the highest average allele (number of alleles, $\mathrm{A}=15.200)$, and HK the lowest $(\mathrm{A}=13.000)$. Hos of $P$. argenteus are less than Hes, indicating lack of heterozygote within populations. Analysis of molecular variance (AMOVA) showed that most variation (95.66\%) occurred within populations, suggesting that this is the main source of total variance. This study will provide useful information for conservation and sustainable exploitation of this important fishery resource.
\end{abstract}

Descriptors: Pampus argenteus, microsatellite, genetic diversity, population structure.

\section{INTRODUCTION}

Pampus argenteus (Perciformes: Stromateidae) is an economically important benthopelagic fish, which is widely distributed along the coast of China, Indian Ocean, Arabian Gulf and North Sea (Davis and Wheeler, 1985; Liu et al., 2002). Due to overfishing and environmental degradation, its numbers reduced year after year (Jin et al.,

Submitted on: 29/January/2019

Approved on: 2/October/ 2019

http://dx.doi.org/10.1590/S1679-87592019025106711

Editor: June Ferraz Dias
2005; Zhang et al., 2007). Thus, new management strategies are urgently needed for the sustainable growth and utilization of this species. For effective fishery management, we need a mass of biological and evolutionary data. Characterization of the genetic variation of this fish species is essential for conserving the genetic resource and restraining the population decline. Therefore, it is necessary to have a clear understanding of the intraspecific genetic diversity and population structure of the species.

Genetic diversity and population structure have vital importance in understanding and managing populations (Palumbi, 2003; Muths et al., 2009). So far, several studies 
on genetic diversity and population structure of $P$. argenteus have been reported (Xu et al., 2008; Peng et al., 2010; Meng et al., 2009; Wu et al., 2012; Zhao et al., 2011a). The markers used were mitochondrial DNA COI, D-loop, RAPD, and isozyme. No studies based on microsatellites of $P$. argenteus is yet available.

Microsatellites or simple sequence repeats (SSR) are short (1-6 bp) repetitive DNA sequences that are highly abundant and almost evenly distributed in genomes. They are generally neutral, highly polymorphic, co-dominant and easily scored with PCR (Goldstein and Schlotterer, 1999). As a more variable marker than RFLP and RAPD, microsatellites have been widely used for population genetics, genome mapping, ecology, and evolution of animals including fishery species for several decades (Goldstein and Schlotterer, 1999; Herwerden et al., 1999; Liu and Cordes, 2004; Vargas-Caro et al., 2017; Kiper et al., 2018).

Population structure is an important factor that should be taken into account by the appropriate regulatory authorities when considering sustainable applications of fish. The aim of this research was to examine the genetic diversity and population structure of $P$. argenteus along the coast of China to provide useful genetic information for the management of this species. In the present study, we used fifteen polymorphic microsatellite markers to assess the genetic diversity and population structure of eight wild populations of $P$. argenteus along the coast of China. This study provide useful information for better understanding the evolution potential and population structure of $\mathrm{P}$. argenteus, and is good for the protection and reasonable utilization of this species.

\section{MATERIALS AND METHODS}

\section{SAMPLING AND DNA EXTRACTION}

From June to August, 2013, a total of 240 wild $P$. argenteus individuals, i.e., 30 individuals of each population, were collected from eight locations along the coast of China (Figure 1). The eight locations are Shidao (SD) of Shandong Province, Lianyungang (LYG) and Lvsi (LS) of Jiangsu Province, Zhoushan (ZS) and Dongtou (DT) of Zhejiang Province, Xiapu (XP) of Fujian Province, Haikou (HK) of Hainan Province, and Beibuwan (BBW) of Guangxi Zhuang Autonomous Region, respectively. The vouchers of the sampled population were deposited in the herbarium of East China Sea Fisheries Research Institute. All individuals were transferred to the laboratory in dry ice and then stored at $-80^{\circ} \mathrm{C}$ before DNA extraction.

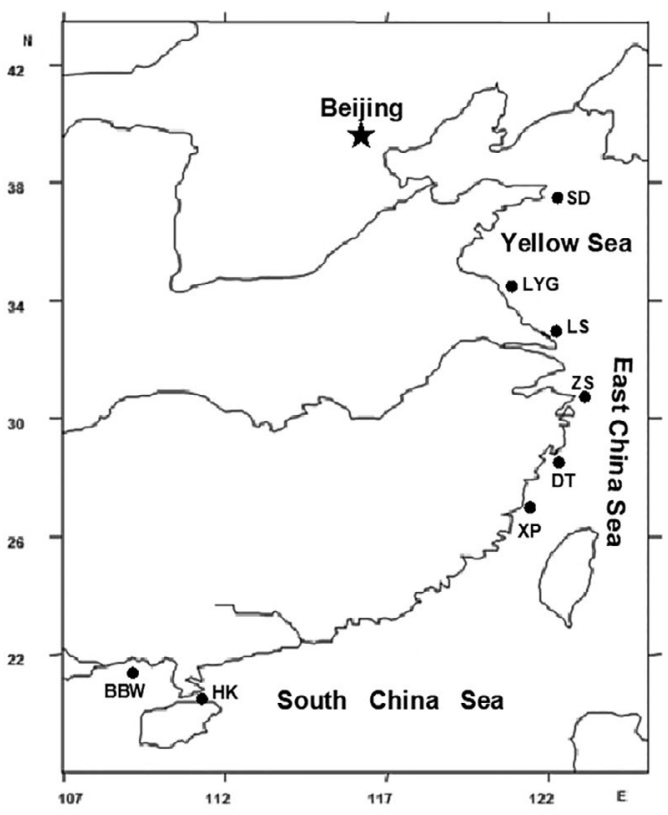

Figure 1. Map of the P. argenteus sampled locations (indicated by circles). The abbreviations correspond to sampled location names, as indicated in text.

Total genomic DNA was extracted from muscle tissue of $P$. argenteus using the standard proteinase $\mathrm{K} / \mathrm{phenol} /$ chloroform procedure (Sambrook et al., 1989). The quality of the extracted DNA was checked using $0.8 \%$ agarose gel electrophoresis, then stored at $-20^{\circ} \mathrm{C}$ for PCR amplification.

\section{Microsatellite GENOTYPING}

Twenty-six pairs of novel polymorphic microsatellite markers for $P$. argenteus were isolated using combined biotin capture method. Fifteen of them, i.e., YC79, YC90, YC140, YC275, YC339, YC353-1, YC353-2, YC459, YC687, YC705, YC731, YC742, YC754, YC764, and YC792 (Table 1), were used for genotyping all the $240 P$. argenteus individuals. Polymerase chain reaction (PCR) amplification was performed in a $15 \mu \mathrm{L}$ reaction volume containing approximately 10-50 ng of genomic DNA, $0.6 \mu \mathrm{M}$ of each primer, $7.5 \mu \mathrm{L} 2 \times$ Taq PCR MasterMix (TIANGEN), with the following thermal cycling conditions: an initial denaturation at $94^{\circ} \mathrm{C}$ for $3 \mathrm{~min}$, followed by 35 cycles of denaturing at $94^{\circ} \mathrm{C}$ for $30 \mathrm{~s}$, annealing at primer-specific annealing temperature $\left(\mathrm{T}_{\mathrm{a}}\right.$, see Table 1$)$ for $30 \mathrm{~s}$, elongation at $72^{\circ} \mathrm{C}$ for $30 \mathrm{~s}$, followed by a final extension at $72^{\circ} \mathrm{C}$ for $7 \mathrm{~min}$. The final PCR products were separated by electrophoresis in denaturing $6 \%$ polyacrylamide gels and visualized by silver staining. The allele sizes 
Table 1. Characterization of fifteen microsatellite loci used in this study.

\begin{tabular}{|c|c|c|c|c|}
\hline Locus & Repeat motif & Primer sequence $\left(5^{\prime}-3^{\prime}\right)$ & $\begin{array}{l}\text { annealing } \\
\text { temperature } \\
\mathrm{Ta}\left({ }^{\circ} \mathrm{C}\right)\end{array}$ & $\begin{array}{c}\text { GenBank } \\
\text { accession } \\
\text { number }\end{array}$ \\
\hline YC79 & $(\mathrm{CT})_{8} \mathrm{~T}(\mathrm{TC})_{8}$ & $\begin{array}{l}\text { F: ACAAGCATAGGATGACTT } \\
\text { R: TACAGGTGGAGATGAGAA }\end{array}$ & 50 & KR091917 \\
\hline YC90 & $(\mathrm{CA})_{11}$ & $\begin{array}{l}\text { F: GGCTAGGGATGAAACTCG } \\
\text { R: GGGAGGGAATCGGAATAG }\end{array}$ & 55 & KR091918 \\
\hline YC140 & $(\mathrm{AC})_{12}$ & $\begin{array}{l}\text { F: GAATAAGCAAACAAACAC } \\
\text { R: ATACAACACTGACAACCT }\end{array}$ & 48 & KR091921 \\
\hline YC275 & $(\mathrm{AC})_{23}$ & $\begin{array}{l}\text { F: AAGTTATGCTCGACCTGA } \\
\text { R: GTCCTTTTATCCCCTGAA }\end{array}$ & 46 & KR091925 \\
\hline YC339 & $(\mathrm{CA})_{8} \ldots(\mathrm{CA})_{5}$ & $\begin{array}{l}\text { F: CTCAGCAGTTCCTCTTTG } \\
\text { R: ATGTAGCGAGTCATTGTG }\end{array}$ & 53 & KR091926 \\
\hline YC353-1 & $(\mathrm{AC})_{10} \ldots(\mathrm{CT})_{15}$ & $\begin{array}{c}\text { F: GATTCGCATAAACAGATAAGT } \\
\text { R: AAGGGGAGGGGAGTAAGT }\end{array}$ & 50 & KR091927 \\
\hline YC353-2 & $(\mathrm{AC})_{13}$ & $\begin{array}{l}\text { F: ATGGCTTCCAATCCTACA } \\
\text { R: ACTGTGCTGCCTGAAATA }\end{array}$ & 50 & KR091928 \\
\hline YC459 & $(\mathrm{CA})_{6}$ & $\begin{array}{l}\text { F: CACGCTGGTGCTAATGGA } \\
\text { R: GTCACAGGGGCAAGTAGA }\end{array}$ & 55 & KR091930 \\
\hline YC687 & $(\mathrm{GT})_{10}(\mathrm{AT})_{6}$ & $\begin{array}{l}\text { F: AATAGCATTCAGACAGTGG } \\
\text { R: CTACAAAGACAGAGACGC }\end{array}$ & 53 & KR091931 \\
\hline YC705 & $(\mathrm{GT})_{6}$ & $\begin{array}{l}\text { F: TGGGGAGAGTGTGATGTG } \\
\text { R: TAGCAGGAGAAGTGTTTTT }\end{array}$ & 48 & KR091932 \\
\hline YC731 & $(\mathrm{TC})_{5} \mathrm{C}(\mathrm{CA})_{8}$ & $\begin{array}{l}\text { F: GTTCAGATAAAGGGAGAT } \\
\text { R: GACCCAGAATAAGTGTAA }\end{array}$ & 50 & KR091935 \\
\hline YC742 & $(\mathrm{TG})_{5}$ & $\begin{array}{c}\text { F: ACAACCGCTCTGTCATAC } \\
\text { R: TACAAACAAGCAAATACACT }\end{array}$ & 48 & KR091936 \\
\hline YC754 & $(\mathrm{CA})_{10}$ & $\begin{array}{l}\text { F: GCGGAGTTCTGCCCTTAT } \\
\text { R: ACTGAGTCCCCATTACCC }\end{array}$ & 55 & KR091937 \\
\hline YC764 & $(\mathrm{TG})_{9}$ & $\begin{array}{l}\text { F: AGAAAGACCCTTATCTCCA } \\
\text { R: CTTCACCTCATTGCCCTC }\end{array}$ & 53 & KR091939 \\
\hline YC792 & $(\mathrm{GT})_{8} \ldots(\mathrm{GT})_{7}$ & $\begin{array}{l}\text { F: GCTGCATCACATCTTGAC } \\
\text { R: GACGTGGATCGACTCTTA }\end{array}$ & 53 & KR091941 \\
\hline
\end{tabular}

were estimated with a 10 bp DNA ladder (Invitrogen) as reference.

\section{STATISTICAL ANALYSIS}

\section{MEASUREMENTS OF GENETIC DIVERSITY}

The number of alleles (A), number of effective alleles (Ae), observed heterozygosity (Ho), expected heterozygosity $(\mathrm{He})$, and the inbreeding coefficient $\left(\mathrm{F}_{\mathrm{IS}}\right)$ for each locus from each population were obtained using GenAlEx 6.0 (Peakall and Smouse, 2006). The diversity level of each genetic locus was evaluated with polymorphic information content (PIC) using the CERVUS version 3.0.3 (Marshall et al., 1998). GENEPOP on the Web (http://genepop.curtin.edu.au/, Raymond and Rousset, 1995) was used to check the deviations from Hardy-Weinberg equilibrium (HWE) and Linkage Disequilibrium (LD) of each locus within each site. HWE and LD tests were performed using the Markov Chain method (10,000 dememorization steps, 100 batches, 5000 iterations).

\section{MEASUREMENTS OF POPULATION DIFFERENTIA- TION}

To study population structure, population-level pairwise $\mathrm{F}_{\mathrm{ST}}$ was analyzed using a permutation with 10,000 replicates. Analysis of molecular variance (AMOVA) were calculated using software ARLEQUIN 3.1 (Excoffier et al., 2005). To examine the genetic relationships among populations, the matrix of Nei's genetic distance of pairwise locations (Nei, 1978) was calculated using the GenAlEx 6.0 (Peakall and Smouse, 2006). Then an unweighted pair-group mean analysis (UPGMA) tree was constructed based on Nei's genetic distance matrices 
using MEGA version 5.0 software (Tamura et al., 2011). In order to provide a visual representation of population subdivision, Principal Component Analysis (PCA) was performed in GenAlEx 6.0 (Peakall and Smouse, 2006).

\section{DEMOGRAPHICAL BOTTLENECK}

We detect recent population declines by computing the heterozygosity excess statistic using the computer program BOTTLENECK with two methods (Cornuet and Luikart, 1996). The first method basing on the principle of heterozygosity excess was executed under two different mutation models: two-phase mutation model (TPM) and stepwise mutation model (SMM), where 95\% and 90\% single-step mutations, and $5 \%$ and $10 \%$ multiple steps mutations with 1,000 simulation iterations were set as recommended by Piry et al. (1999). SMM was used because microsatellite loci appear to evolve under a mutation model that is more similar to the SMM than the infinite allele model (IAM) (Valdes et al., 1993; Shriver et al., 1993). The second method, mode-shift test (Luikart and Cornuet, 1998), was used to detect a potential bottlenecked population using an L-shaped distribution of allele frequency as mutation-drift equilibrium.

\section{RESULTS}

\section{GENETIC DIVERSITY}

All the 15 microsatellite markers were well amplified in the eight populations of $P$. argenteus. Of the $120 \mathrm{HWE}$ tests across all 15 loci, 38 were conformed to HWE (Table Sup) within each sample location after applying sequential Bonferroni corrections (minimum adjusted alpha = 0.00050) (Rice, 1989). In addition, significant genotypic LD for multiple comparisons of 15 loci within populations was detected in 18 out of 1680 tests (minimum adjusted alpha $=0.00015)($ Rice, 1989) after sequential Bonferroni correction. Thus, we think that most microsatellite loci could be deemed as genetically independent for further analysis.

All 15 loci were polymorphic in all of the eight studied populations of $P$. argenteus with high allelic diversity and heterozygosity (Table Sup.). A total of 139 alleles were detected at the 15 microsatellite loci across the eight populations. The number of private alleles for the eight populations are 9 (SD), 10 (LYG), 7 (LS), 6 (ZS), 7 (DT), $18(\mathrm{XP}), 18(\mathrm{HK})$, and $23(\mathrm{BBW})$, respectively. For A, LS was the highest population with $A=15.200$, while $\mathrm{HK}$ was the least variable one with $\mathrm{A}=13.000$. For $\mathrm{Ae}$, DT was the highest with $\mathrm{Ae}=10.222$, while $\mathrm{HK}$ was the least with $\mathrm{Ae}=8.340$.

For the eight populations, the average polymorphism information content (PIC) ranged from 0.854 (HK) to 0.879 (LS) per location. The average inbreeding coefficient $\left(\mathrm{F}_{\mathrm{IS}}\right)$ ranged from -0.200 (YC459-XP) to 0.870 (YC687-HK) with an average value 0.363 per locus, and ranged between 0.290 (DT) and $0.426(\mathrm{HK})$ for populations (Table Sup.), suggesting that there is high inbreeding in these eight $P$. argenteus populations. Observed and expected heterozygosity $\left(\mathrm{H}_{\mathrm{o}}\right.$ and $\left.\mathrm{H}_{\mathrm{e}}\right)$ ranged from 0.100 to 1.000 and from 0.669 to 0.934 per locus-location combination, while from 0.504 (HK) to 0.627 (DT) and from 0.867 (HK) to 0.889 (LS) per location, respectively (Table Sup.). Within sampling locations, the mean expected heterozygosities $\left(\mathrm{H}_{\mathrm{e}}\right)$ were consistently higher than the observed one $\left(\mathrm{H}_{\mathrm{o}}\right)$ across all loci, which revealed a deficit of heterozygosity among the samples.

\section{POPUlation STRUCTURE}

Significant genetic heterozygosity among the eight populations was indicated by AMOVA analysis. The results showed that $4.34 \%$ of total genetic variation came from among population variation, while the within population variation explained $95.66 \%$ of total variation. Genetic differentiation between populations was analyzed using $\mathrm{F}_{\mathrm{ST}}$. The overall $\mathrm{F}_{\mathrm{ST}}$ value over all locations and loci was statistically different from zero (Fixation Index $\mathrm{F}_{\mathrm{ST}}=0.0434, p<0.001$ ) (Table 2). Pairwise $\mathrm{F}_{\mathrm{ST}}$ comparing population pairs ranged from 0.022 (DT and ZS) to 0.074 (HK and XP) (Table 3). The highest genetic differentiation between populations using $\mathrm{F}_{\mathrm{ST}}$ was between the populations HK and XP, while the lowest differentiation was between DT and ZS (Table 3). The results of $\mathrm{F}_{\mathrm{ST}}$ indicated that there was low but statistically significant genetic differentiation among the populations.

UPGMA phylogenetic trees (Figure 2) were constructed on the basis of Nei's genetic distance matrix (Table 3). Eight populations were divided into two main clusters: HK and BBW populations formed Cluster I; ClusterIIincludes the remaining six populations. Cluster II is consisted of three subgroups, i.e., subgroup 1 includes XP, subgroup 2 includes LS, and subgroup 3 includes two SD, LYG, ZS, and DT (Figure 3). Mantel Test showed that there are significant linear correlation between geographic distances and genetic distances with $\mathrm{R}^{2}=0.8012$ (data not shown), which could imply isolation by distance. Furthermore, the PCA analysis also showed the HK and BBW populations 
Table 2. AMOVA analysis of eight populations of $P$. argenteus.

\begin{tabular}{lcccccc}
\hline Source of variation & d.f & Sum of squares & $\begin{array}{c}\text { Variance } \\
\text { components }\end{array}$ & $\begin{array}{c}\text { Percentage of } \\
\text { variation (\%) }\end{array}$ & $\begin{array}{c}\text { Fixation Index } \\
(\text { FST) }\end{array}$ & $p$ \\
\hline Among populations & 7 & 193.265 & $0.30572 \mathrm{~V}^{\mathrm{a}}$ & 4.34 & 0.0434 & 0.0000 \\
within populations & 232 & 2149.650 & $2.51932 \mathrm{~V}^{\mathrm{b}}$ & 95.66 & & \\
Total & 239 & 2343 & 2.82504 & & & \\
\hline
\end{tabular}

Table 3. Estimates of pairwise FST values (below diagonal) and Nei's Genetic Distance (above diagonal) between eight populations of $P$. argenteus detected by 15 microsatellites.

\begin{tabular}{lcccccccc}
\hline Population & SD & LYG & LS & ZS & DT & XP & HK & BBW \\
\hline SD & - & 0.450 & 0.560 & 0.440 & 0.490 & 0.535 & 1.141 & 1.162 \\
LYG & $0.029 * * *$ & - & 0.501 & 0.496 & 0.412 & 0.641 & 1.115 & 0.948 \\
LS & $0.036 * * *$ & $0.032 * * *$ & - & 0.519 & 0.463 & 0.628 & 0.976 & 0.975 \\
ZS & $0.028 * * *$ & $0.033 * * *$ & $0.033^{* * *}$ & - & 0.359 & 0.494 & 1.084 & 1.025 \\
DT & $0.033 * * *$ & $0.027 * * *$ & $0.030^{* * *}$ & $0.022^{* * *}$ & - & 0.507 & 1.027 & 0.987 \\
XP & $0.039 * * *$ & $0.047 * * *$ & $0.044 * * *$ & $0.036 * * *$ & $0.038^{* * *}$ & - & 1.042 & 1.068 \\
HK & $0.072 * * *$ & $0.072 * * *$ & $0.064 * * *$ & $0.071 * * *$ & $0.069 * * *$ & $0.074 * * *$ & - & 0.579 \\
BBW & $0.071 * * *$ & $0.063 * * *$ & $0.062 * * *$ & $0.066 * * *$ & $0.066^{* * *}$ & $0.073 * * *$ & $0.046 * * *$ & - \\
\hline
\end{tabular}

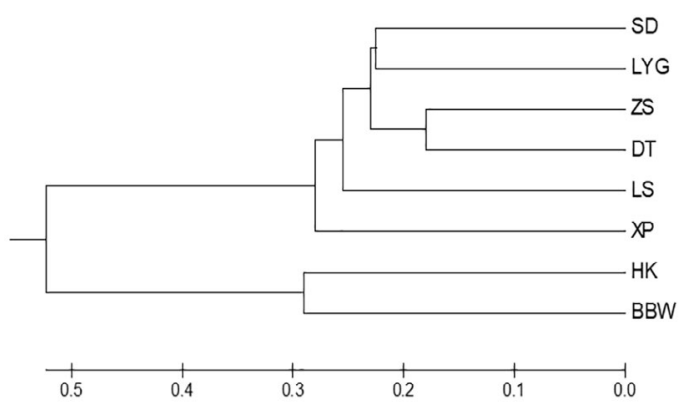

Figure 2. Unweighted Pair-group Method with Arithmetic Means tree (UPGMA) of eight populations of $P$. argenteus based on Nei's genetic distance.

Principal Coordinates

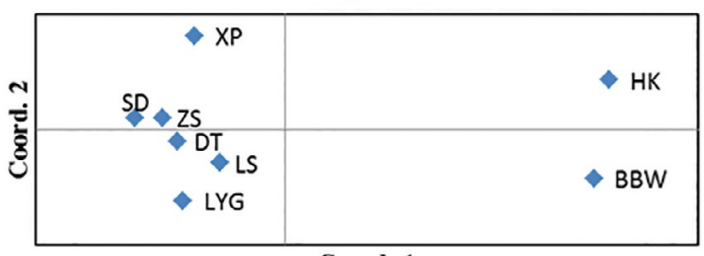

Coord. 1

Figure 3. Principal component analysis (PCA) of eight populations of $P$. argenteus.

to be genetically distinct from the other six locations (Figure 3). These results are consistent with the $\mathrm{F}_{\mathrm{ST}}$ and Nei's distance tests.

\section{DEMOGRAPHIC BOTTLENECK}

Analysis of recent population declines of $P$. argenteus was detected using the Wilcoxon signed-rank test in BOTTLENECK under two models of microsatellite evolution (SMM and TPM)(Table 4). Excepted TPM (90\%) for SD and DT, the probability values of the bottleneck test all above 0.05 (Table 4), suggesting no significant excess of heterozygosity in most populations. It indicated that there was no genetic bottleneck in most of the eight populations due to mutation-drift equilibrium. In addition, the mode-shift test showed that all populations were in normal L-shaped pattern of the allele frequency distributions (Table 4), revealing the lack of population declines in the recent history of $P$. argenteus.

\section{DISCUSSION}

In this study, we examined the genetic diversity and population structure of eight wild populations of $P$. argenteus using 15 highly polymorphic microsatellites. We observed low but significant genetic differences in the spatial distribution of $P$. argenteus along the coast of China. The results suggested a high level of population genetic diversity of $P$. argenteus (A:13.000-15.200, Ho:0.5040.627, He: 0.867-0.889, and PIC:0.854-0.879), which is in line with the previous studies that showed a high level of genetic diversity in $P$. argenteus using RAPD, AFLP and mtDNA (Meng et al., 2009; Zhao et al., 2011a; Peng et al., 
Table 4. $p$-values of bottleneck tests for detecting the recent population declines of $P$. argenteus using stepwise mutation model (SMM), two phased mutation model (TPM), and mode shift indicator.

\begin{tabular}{|c|c|c|c|c|c|}
\hline \multirow{2}{*}{ Population } & \multicolumn{4}{|c|}{ Heterozygosity excess ( $p$ value) } & \multirow{2}{*}{ Mode-shif } \\
\hline & SMM $(90 \%)$ & SMM $(95 \%)$ & ТРМ $(90 \%)$ & TPM $(95 \%)$ & \\
\hline SD & 0.27686 & 0.30280 & $0.00336 * *$ & 0.07300 & normal \\
\hline LYG & 0.76154 & 0.80396 & 0.25238 & 0.42120 & normal \\
\hline LS & 0.71973 & 0.97797 & 0.18762 & 0.42120 & normal \\
\hline $\mathrm{ZS}$ & 0.71973 & 0.67877 & 0.05536 & 0.38940 & normal \\
\hline DT & 0.33026 & 0.27686 & $0.02557 *$ & 0.15143 & normal \\
\hline $\mathrm{XP}$ & 0.10699 & 0.15143 & 0.35913 & 0.42120 & normal \\
\hline HK & 0.84692 & 0.89038 & 0.10699 & 0.48871 & normal \\
\hline BBW & 0.84692 & 0.76154 & 0.30280 & 0.52448 & normal \\
\hline
\end{tabular}

*, Signification $p$ value $<0.05$; **, Extremely signification $p$ value $<0.01 .{ }^{*}$, significant evidence of a population decline from bottleneck.

2009a; Wu et al., 2012). Genetic diversity is not only the consequence of evolution, but also represented the evolution potential of animals. In order to be fit for survival, animals accumulated more genetic diversity to ensure their increase of the fitness for many kinds of environmental pressures (Liu et al., 2010). P. argenteus may use a relative high genetic diversity to adopt its rigorous habitats during its evolution.

The amount of effective alleles (Ae) was obviously less than that of the observed alleles (A) (Table Sup.), indicating that some alleles were lost between the populations studied in this study. The amount of alleles is very important to maintain populations because it provides the necessary spectrum of genotypes for adaptive response to changing environments (Thai et al., 2007). The loss of genetic diversity will prevent future improvements via selection of the species to a certain extent. The most likely explanation for the loss of alleles may be that the wild population was under stress from overfishing and deterioration in the environment resulting in less recruitment (Alam and Islam, 2005). In order to prevent the alleles from losing and to conserve the genetic resource, we could strengthen the conservation and supervision of wild resources and forbid overfishing in the natural waters.

Generally, marine species are capable of migration over long distances, showing little or no genetic differentiation in geographic scales because of long distance pelagic dispersal potential during planktonic egg, larval, or adult history stages coupled with an absence of physical barriers to movement between ocean basins or adjacent continental margins (Hewitt, 2000). The small but highly significant values of pairwise $\mathrm{F}_{\mathrm{ST}}$ in the present study indicated that the $P$. argenteus have genetic differentiation among populations, and more than $95.66 \%$ of the total genetic variation was among individuals within populations (Table 2). UPGMA and PCA analysis indicated that the population of eight $P$. argenteus can divided into two major groups: one group including populations of $P$. argenteus in the South China Sea (SCS) and the other group consisting populations of $P$. argenteus in the Yellow Sea (YS) and the East China Sea (ECS). Earlier studies using RAPD and mtDNA (Meng et al., 2009; Peng et al., 2009) did support the idea that the populations from the South China Sea are genetically different from other populations. In all, these results revealed that there are different isolation patterns between two major groups and significant population differentiation throughout the examined range of sampled locations. Populations of $P$. argenteus seem to show high levels of gene flow between ECS and YS groups. A complex system of surface currents is likely the main factor influencing gene flow. The China Coastal Current and Yellow Sea Warm Current, including outflow of water from the Yellow Sea to the East China Sea along the China coast and inflow from the East China Sea to the Yellow Sea along the west coast of Korea (Li et al., 2000), respectively, could contribute to mixing of YS and ECS groups. The gene flow between populations from the South China Sea and other populations may be limited by some factors such as oceanographic characteristics and life history.

Zhao et al. (2011b) indicates that LYG and ZS samples have close relationship. However, our study results show that the normalized Euclidean distance between ZS and DT samples was shorter than all other pairwise distances. In general, morphological differences of $P$. argenteus among Chinese coastal waters can be discerned by multivariate morphometrics methods. Our study with microsatellite as marker showed significant genetic differentiation 
in $P$. argenteus, which were to some extend different from the results based on mitochondrial DNA gene sequences (Peng et al., 2009b; Wu et al., 2012). The reasons leading to this divergence may include intrinsic variability of the population, sample size, spatial replication, and the number and characteristics of the marker loci used (Curley and Gillings, 2009). More samples should be collected from all over Chinese coastal waters including Bohai Sea, Yellow Sea, East China Sea and South China Sea to allow for a more comprehensive picture of genetic variation of this species.

\section{ACKNOWLEDGEMENTS}

This work was supported by Central Public-interest Scientific Institution Basal Research Fund, ECSFR, CAFS (No.2012M09) and Science and Technology Commission of Shanghai Municipality (Shanghai Natural Science Foundation No. 19ZR1470100).

\section{REFERENCES}

ALAM, S. \& ISLAM, S. 2005. Population genetic structure of Catla catla (Hamilton) revealed by microsatellite DNA markers. Aquaculture, 246, 151-160.

CORNUET, J. M. \& LUIKART, G. 1996. Description and power analysis of two tests for detecting recent population bottlenecks from allele frequency data. Genetics, 144, 2001-2014.

CURLEY, B. G. \& GILLINGS, M. R. 2009. Population connectivity in the temperate damselfish Parma microlepis: analysis of genetic structure across multiple spatial scales. Marine Biology, 156, 381-393.

DAVIS, P. \& WHEELER, A. 1985. The occurrence of Pampus argenteus (Euphrasen, 1788), (Osteichthyes, Perciformes, Stromateoidei, Stromateidae) in the North Sea. Journal of Fish Biology, 26, 105-109.

EXCOFFIER, L., LAVAL, G. \& SCHNEIDER, S. 2005. Arlequin version 3.0: An integrated software package for population genetics data analysis. Evolutionary Bioinformatics, 1, 47-50.

GOLDSTEIN, D. B. \& SCHLOTTERER, C. 1999. Microsatellites: Evolution and Applications, Oxford, Oxford University Press.

HERWERDEN, L. V., BLAIR, D. \& AGATSUMA, T. 1999. Genetic diversity in parthenogenetic triploid Paragonimus westermani. International Journal for Parasitology, 29, 14771482.

HEWITT, G. M. 2000. The genetic legacy of the Quaternary ice ages. Nature, 405, 907-913

JIN, X., ZHAO, X., MENG, T. \& CUI, Y. M. 2005. Biology Resources and Habitat Environment in Yellow and Bohai Seas, Beijing, Science Press. [In Chinese]

KIPER, I. E., BLOOMER, P., BORSA, P. \& HOAREAU, T. B. 2018. Characterization of genome-wide microsatellite markers in rabbitfishes, an important resource for artisanal fisheries in the Indo-West Pacific. Molecular Biology Reports, $45,19-25$.
LI, N. S., ZHAO, S. L. \& WASILIEV, B. 2000. Geology of marginal sea in the Northwest Pacific, Harbin, Heilongjiang Education Press. [In Chinese]

LIU, J., LI, C. S. \& LI, X. S. 2002. Phylogeny and biogeography of Chinese pomfret fishes (Pisces: Stromateidae). Studia Marina Sinica, 44, 235-239. [In Chinese]

LIU, Z. J. \& CORDES, J. F. 2004. DNA marker technologies and their applications in aquaculture genetics. Aquaculture, 238, $1-137$.

LIU, W. X., LIU, W. H., WU, J., GAO, A. N. \& LI, L. H. 2010. Analysis of genetic diversity in natural populations of $P s a$ thyrostachys huashanica Keng using microsatellite (SSR) markers. Journal of Integrative Agriculture, 9, 463-471.

LUIKART, G. \& CORNUET, J. M. 1998. Empirical Evaluation of a Test for Identifying Recently Bottlenecked Populations from Allele Frequency Data. Conservation Biology, 12, 228 237.

MARSHALL, T. C., SLATE, J., KRUUK, L. E. B. \& PEMBERTON, J. M. 1998. Statistical confidence for likelihood-based paternity inference in natural populations. Molecular Ecology, 17, 639-655.

MENG, Y. Y., ZHANG, L. Z., ZHAO, F., SHI, Z. H. \& ZHUANG, P. 2009. Preliminary study on the genetic diversity of four geographic populations of silver pomfret (Pampus argenteus). Marine Fisheries, 31, 48-52. [In Chinese]

MUTHS, D., GREWE, P., JEAN, C. \& BOURJEA, J. 2009. Genetic population structure of the Swordfish (Xiphias gladius) in the southwest Indian Ocean: Sex-biased differentiation, congruency between markers and its incidence in a way of stock assessment. Fisheries Research, 97, 263-269.

NEI, M. 1978. Estimation of average heterozygosity and genetic distance from a small number of individuals. Genetics, 89 , 583-590.

PALUMBI, S. R. 2003. Population genetics, demographic connectivity, and the design of marine reserves. Ecological Applications, 13, 146-158.

PEAKALL, R. \& SMOUSE, P. E. 2006. GENALEX 6: genetic analysis in Excel. Population genetic software for teaching and research. Molecular Ecology Resources, 6, 288-295.

PENG, S. M., SHI, Z. H., HOU, J. L., WANG, W., ZHAO, F. \& ZHANG, H. 2009a. Genetic diversity of silver pomfret (Pampus argenteus) populations from the China Sea based on mitochondrial DNA control region sequences. Biochemical Systematics and Ecology, 37, 626-632.

PENG, S. M., SHI, Z. H., HOU, J. L., ZHANG, H. \& ZHAO, F. 2009b. Genetic diversity of three wild silver pomfret (Pampus argenteus) populations based on COI gene sequences. Journal of Shanghai Ocean University, 18, 398-402.

PENG, S. M., SHI, Z. H. \& HOU, J. L. 2010. Comparative analysis on the genetic diversity of cultured and wild silver pomfret populations based on $\mathrm{mtD}$-loop and COI gene. Journal of $\mathrm{Fi}$ sheries of China, 34, 19-25. [In Chinese]

PIRY, S., LUIKART, G. \& CORNUET, J. M. 1999. BOTTLENECK: a computer program for detecting recent reductions in the effective population size using allele frequency data. Journal of Heredity, 90, 502-503.

RAYMOND, M. \& ROUSSET, F. 1995. Genepop (version-1.2): Population genetics software for exact tests and ecumenicism. Journal of Heredity, 86, 248-249.

RICE, W. R. 1989. Analyzing tables of statistical tests. Evolution, $43,223-225$. 
SAMBROOK, J., FRITSCH, E. F. \& MANIATIS, T. 1989. Molecular cloning: a laboratory manual, New York, Cold Spring Harbor Laboratory Press.

SHRIVER, M. D., JIN, L., CHAKRABORTY, R. \& BOERWINKLE, E. 1993. Vntr Allele Frequency Distributions under the Stepwise Mutation Model: A Computer Simulation Approach. Genetics, 134, 983-993.

TAMURA, K., PETERSON, D., PETERSON, N., STECHER, G., NEI, M. \& KUMAR, S. 2011. MEGA5: Molecular Evolutionary Genetics Analysis Using Maximum Likelihood, Evolutionary Distance, and Maximum Parsimony Methods. Molecular Biology and Evolution, 28, 2731-2739.

THAI, B. T., BURRIDGE, C. P. \& AUSTIN, C. M. 2007. Genetic diversity of common carp (Cyprinus carpio L.) in Vietnam using four microsatellite loci. Aquaculture, 269, 174-186.

VALDES, A. M., SLATKIN, M. \& FREIMER, N. B. 1993. Allele frequencies at microsatellite loci: the stepwise mutation model revisited. Genetics, 133, 737-749.

VARGAS-CARO, C., BUSTAMANTE, C., BENNETT, M. B. \& OVENDEN, J. R. 2017. Towards sustainable fishery management for skates in South America: The genetic population structure of Zearaja chilensis and Dipturus trachyderma (Chondrichthyes, Rajiformes) in the south-east Pacific Ocean. PLoS One, 12, e0172255.
WU, R. X., LIANG, X. H. \& ZHUANG, Z. M. 2012. Mitochondrial COI sequance variation of silver pomfret (Pampus argenteus) from Chinese coastal waters. Acta Zootaxonomica Sinica, 37, 480-488. [In Chinese]

XU, G. P., LI, X. G., ZHONG, X. M., LIU, P. T. \& TANG, J. H. 2008. Research on genetic diversity of Pampus argentells population in Jiangsu Province by isozyme and ISSR. Jiangsu Agricultural Sciences, 36, 80-82. [In Chinese]

ZHANG, Q. H., CHENG, J. H., XU, H. X. \& ZHENG, Y. J. 2007. Fishery Resources and Its Sustainable Utilization in the East China Sea Region, Shanghai, Fudan University Press. [In Chinese]

ZHAO, F., DONG, Y., ZHUANG, P., ZHANG, T., ZHANG, L. Z. \& SHI, Z. H. 2011a. Genetic diversity of silver pomfret (Pampus argenteus) in the Southern Yellow and East China Seas. Biochemical Systematics and Ecology, 39, 145-150.

ZHAO, F., ZHUANG, P., ZHANG, L. Z., SHI, Z. H. 2011b. Morphological variation of Pampus argenteus among five samples near the coastal area of the Bohai Sea, Huanghai Sea and East China Sea. Acta Oceanologica Sinica, 33, 104-110. 
Supplementary Table

Table Sup. Statistics for genetic variation at 15 microsatellite loci in eight populations of $P$. argenteus.

\begin{tabular}{|c|c|c|c|c|c|c|c|c|}
\hline \multirow{2}{*}{ Locus } & \multirow{2}{*}{ Population } & \multicolumn{7}{|c|}{ Parameters } \\
\hline & & $\mathbf{A}$ & Ae & Но & $\mathrm{He}$ & PIC & PHWE & Fis \\
\hline \multirow[t]{8}{*}{ YC79 } & SD & 17 & 13.333 & 0.567 & 0.925 & 0.920 & $0.0000 *$ & 0.387 \\
\hline & LYG & 14 & 9.524 & 0.767 & 0.895 & 0.886 & 0.0019 & 0.143 \\
\hline & LS & 17 & 13.636 & 0.767 & 0.927 & 0.922 & 0.0040 & 0.173 \\
\hline & $\mathrm{ZS}$ & 16 & 12.950 & 0.667 & 0.923 & 0.917 & 0.0004 & 0.278 \\
\hline & DT & 16 & 12.245 & 0.533 & 0.918 & 0.913 & $0.0000 *$ & 0.419 \\
\hline & $\mathrm{XP}$ & 16 & 10.169 & 0.767 & 0.902 & 0.894 & 0.0526 & 0.150 \\
\hline & $\mathrm{HK}$ & 10 & 7.531 & 0.433 & 0.867 & 0.853 & $0.0000 *$ & 0.500 \\
\hline & BBW & 12 & 9.278 & 0.433 & 0.892 & 0.882 & $0.0000 *$ & 0.514 \\
\hline \multirow[t]{8}{*}{ YC90 } & SD & 15 & 12.500 & 0.333 & 0.920 & 0.914 & $0.0000 *$ & 0.638 \\
\hline & LYG & 15 & 9.836 & 0.333 & 0.898 & 0.890 & $0.0000^{*}$ & 0.629 \\
\hline & LS & 14 & 11.613 & 0.533 & 0.914 & 0.907 & $0.0000^{*}$ & 0.416 \\
\hline & $\mathrm{ZS}$ & 15 & 10.588 & 0.400 & 0.906 & 0.898 & $0.0000^{*}$ & 0.558 \\
\hline & DT & 14 & 11.111 & 0.667 & 0.910 & 0.903 & 0.0025 & 0.267 \\
\hline & $\mathrm{XP}$ & 16 & 10.227 & 0.533 & 0.902 & 0.894 & $0.0000 *$ & 0.409 \\
\hline & $\mathrm{HK}$ & 12 & 8.571 & 0.367 & 0.883 & 0.872 & $0.0000 *$ & 0.585 \\
\hline & BBW & 11 & 8.451 & 0.300 & 0.882 & 0.870 & $0.0000^{*}$ & 0.660 \\
\hline \multirow[t]{8}{*}{ YC140 } & SD & 16 & 9.184 & 0.733 & 0.891 & 0.882 & 0.0008 & 0.177 \\
\hline & LYG & 19 & 14.516 & 0.867 & 0.931 & 0.927 & 0.0042 & 0.069 \\
\hline & LS & 19 & 13.433 & 0.833 & 0.926 & 0.921 & 0.0001 & 0.100 \\
\hline & $\mathrm{ZS}$ & 17 & 10.843 & 0.800 & 0.908 & 0.901 & 0.0621 & 0.119 \\
\hline & DT & 19 & 12.766 & 0.833 & 0.922 & 0.916 & 0.3156 & 0.096 \\
\hline & XP & 13 & 8.000 & 0.433 & 0.875 & 0.863 & $0.0000 *$ & 0.505 \\
\hline & HK & 12 & 4.972 & 0.533 & 0.799 & 0.781 & $0.0000 *$ & 0.332 \\
\hline & BBW & 12 & 4.700 & 0.533 & 0.787 & 0.761 & $0.0000 *$ & 0.323 \\
\hline \multirow[t]{8}{*}{ YC275 } & SD & 18 & 11.921 & 0.800 & 0.916 & 0.910 & $0.0000 *$ & 0.127 \\
\hline & LYG & 20 & 15.126 & 0.833 & 0.934 & 0.930 & $0.0000 *$ & 0.108 \\
\hline & LS & 21 & 13.043 & 0.867 & 0.923 & 0.918 & 0.1694 & 0.061 \\
\hline & $\mathrm{ZS}$ & 17 & 13.534 & 0.833 & 0.926 & 0.921 & 0.0593 & 0.100 \\
\hline & DT & 20 & 14.876 & 0.900 & 0.933 & 0.929 & 0.0226 & 0.035 \\
\hline & $\mathrm{XP}$ & 15 & 7.531 & 0.733 & 0.867 & 0.856 & $0.0000^{*}$ & 0.154 \\
\hline & HK & 18 & 13.235 & 1.000 & 0.924 & 0.919 & $0.0000 *$ & -0.082 \\
\hline & BBW & 18 & 10.843 & 0.933 & 0.908 & 0.901 & $0.0000 *$ & -0.028 \\
\hline \multirow[t]{8}{*}{ YC339 } & $\mathrm{SD}$ & 11 & 6.844 & 0.300 & 0.854 & 0.838 & $0.0000 *$ & 0.649 \\
\hline & LYG & 12 & 7.895 & 0.600 & 0.873 & 0.862 & $0.0000^{*}$ & 0.313 \\
\hline & LS & 12 & 8.612 & 0.333 & 0.884 & 0.873 & $0.0000^{*}$ & 0.623 \\
\hline & $\mathrm{ZS}$ & 11 & 8.867 & 0.533 & 0.887 & 0.877 & $0.0000^{*}$ & 0.399 \\
\hline & DT & 13 & 7.759 & 0.467 & 0.871 & 0.858 & $0.0000 *$ & 0.464 \\
\hline & XP & 11 & 8.333 & 0.633 & 0.880 & 0.868 & 0.0002 & 0.280 \\
\hline & HK & 11 & 6.475 & 0.267 & 0.846 & 0.829 & $0.0000 *$ & 0.685 \\
\hline & BBW & 12 & 7.792 & 0.400 & 0.872 & 0.859 & $0.0000 *$ & 0.541 \\
\hline \multirow[t]{2}{*}{ YC353-1 } & $\mathrm{SD}$ & 18 & 12.245 & 0.733 & 0.918 & 0.913 & 0.0230 & 0.201 \\
\hline & LYG & 19 & 13.534 & 0.733 & 0.926 & 0.921 & 0.0001 & 0.208 \\
\hline
\end{tabular}




\begin{tabular}{|c|c|c|c|c|c|c|c|c|}
\hline & LS & 21 & 14.754 & 0.833 & 0.932 & 0.928 & 0.0077 & 0.106 \\
\hline & ZS & 19 & 12.857 & 0.633 & 0.922 & 0.917 & 0.0001 & 0.313 \\
\hline & DT & 19 & 13.433 & 0.633 & 0.926 & 0.921 & $0.0000 *$ & 0.316 \\
\hline & $\mathrm{XP}$ & 13 & 7.792 & 1.000 & 0.872 & 0.859 & 0.0110 & -0.147 \\
\hline & HK & 14 & 7.895 & 0.767 & 0.873 & 0.861 & 0.0005 & 0.122 \\
\hline & BBW & 16 & 9.783 & 0.900 & 0.898 & 0.889 & 0.4368 & -0.002 \\
\hline \multirow[t]{8}{*}{ YC353-2 } & SD & 11 & 6.642 & 0.467 & 0.849 & 0.833 & $0.0000 *$ & 0.451 \\
\hline & LYG & 11 & 8.295 & 0.733 & 0.879 & 0.868 & 0.0089 & 0.166 \\
\hline & LS & 14 & 8.696 & 0.433 & 0.885 & 0.875 & $0.0000 *$ & 0.510 \\
\hline & $\mathrm{ZS}$ & 18 & 10.345 & 0.600 & 0.903 & 0.897 & $0.0000^{*}$ & 0.336 \\
\hline & DT & 16 & 10.465 & 0.467 & 0.904 & 0.897 & $0.0000^{*}$ & 0.484 \\
\hline & XP & 11 & 6.569 & 0.733 & 0.848 & 0.831 & 0.0002 & 0.135 \\
\hline & HK & 11 & 6.923 & 0.667 & 0.856 & 0.841 & 0.0006 & 0.221 \\
\hline & BBW & 12 & 8.295 & 0.800 & 0.879 & 0.868 & 0.0938 & 0.090 \\
\hline \multirow[t]{8}{*}{ YC459 } & SD & 10 & 5.902 & 0.400 & 0.831 & 0.810 & $0.0000 *$ & 0.518 \\
\hline & LYG & 9 & 3.766 & 0.367 & 0.734 & 0.698 & $0.0000 *$ & 0.501 \\
\hline & LS & 12 & 5.085 & 0.500 & 0.803 & 0.787 & $0.0000 *$ & 0.378 \\
\hline & $\mathrm{ZS}$ & 7 & 3.358 & 0.267 & 0.702 & 0.654 & $0.0000 *$ & 0.620 \\
\hline & DT & 6 & 3.025 & 0.367 & 0.669 & 0.618 & $0.0000 *$ & 0.452 \\
\hline & XP & 10 & 6.000 & 1.000 & 0.833 & 0.813 & $0.0000 *$ & -0.200 \\
\hline & HK & 15 & 8.451 & 0.167 & 0.882 & 0.871 & $0.0000^{*}$ & 0.811 \\
\hline & BBW & 12 & 5.248 & 0.267 & 0.809 & 0.792 & $0.0000 *$ & 0.671 \\
\hline \multirow[t]{8}{*}{ YC687 } & SD & 14 & 10.588 & 0.233 & 0.906 & 0.898 & $0.0000 *$ & 0.742 \\
\hline & LYG & 18 & 9.677 & 0.300 & 0.897 & 0.888 & $0.0000 *$ & 0.665 \\
\hline & LS & 14 & 11.250 & 0.400 & 0.911 & 0.904 & $0.0000 *$ & 0.561 \\
\hline & $\mathrm{ZS}$ & 18 & 12.000 & 0.467 & 0.917 & 0.911 & $0.0000^{*}$ & 0.491 \\
\hline & DT & 18 & 11.250 & 0.567 & 0.911 & 0.905 & $0.0000 *$ & 0.378 \\
\hline & XP & 20 & 11.921 & 0.633 & 0.916 & 0.910 & $0.0000^{*}$ & 0.309 \\
\hline & HK & 6 & 4.327 & 0.100 & 0.769 & 0.733 & $0.0000^{*}$ & 0.870 \\
\hline & BBW & 9 & 5.696 & 0.200 & 0.824 & 0.803 & $0.0000 *$ & 0.757 \\
\hline \multirow[t]{8}{*}{ YC705 } & SD & 18 & 13.043 & 0.633 & 0.923 & 0.918 & $0.0000 *$ & 0.314 \\
\hline & LYG & 18 & 10.976 & 0.633 & 0.909 & 0.902 & $0.0000^{*}$ & 0.303 \\
\hline & LS & 19 & 13.433 & 0.633 & 0.926 & 0.921 & $0.0000^{*}$ & 0.316 \\
\hline & ZS & 18 & 13.235 & 0.733 & 0.924 & 0.919 & 0.0002 & 0.207 \\
\hline & DT & 17 & 14.876 & 0.800 & 0.933 & 0.929 & 0.1004 & 0.142 \\
\hline & $\mathrm{XP}$ & 20 & 14.063 & 0.633 & 0.929 & 0.924 & $0.0000 *$ & 0.318 \\
\hline & $\mathrm{HK}$ & 20 & 14.400 & 0.700 & 0.931 & 0.926 & $0.0000 *$ & 0.248 \\
\hline & BBW & 22 & 14.754 & 0.833 & 0.932 & 0.928 & 0.0067 & 0.106 \\
\hline \multirow[t]{8}{*}{ YC731 } & SD & 13 & 9.890 & 0.600 & 0.899 & 0.890 & $0.0000 *$ & 0.333 \\
\hline & LYG & 13 & 9.626 & 0.200 & 0.896 & 0.887 & $0.0000 *$ & 0.777 \\
\hline & LS & 13 & 8.531 & 0.433 & 0.883 & 0.872 & $0.0000 *$ & 0.509 \\
\hline & ZS & 15 & 10.112 & 0.533 & 0.901 & 0.893 & $0.0000^{*}$ & 0.408 \\
\hline & DT & 11 & 8.612 & 0.467 & 0.884 & 0.873 & $0.0000^{*}$ & 0.472 \\
\hline & XP & 10 & 5.625 & 0.400 & 0.822 & 0.801 & $0.0000^{*}$ & 0.514 \\
\hline & HK & 8 & 6.186 & 0.167 & 0.838 & 0.819 & $0.0000 *$ & 0.801 \\
\hline & BBW & 13 & 8.295 & 0.267 & 0.879 & 0.867 & $0.0000 *$ & 0.697 \\
\hline
\end{tabular}




\begin{tabular}{|c|c|c|c|c|c|c|c|c|}
\hline \multirow[t]{8}{*}{ YC742 } & $\mathrm{SD}$ & 9 & 4.523 & 0.233 & 0.779 & 0.754 & $0.0000^{*}$ & 0.700 \\
\hline & LYG & 9 & 6.767 & 0.300 & 0.852 & 0.835 & $0.0000^{*}$ & 0.648 \\
\hline & LS & 10 & 5.751 & 0.633 & 0.826 & 0.804 & $0.0000^{*}$ & 0.233 \\
\hline & $\mathrm{ZS}$ & 12 & 6.792 & 0.700 & 0.853 & 0.836 & 0.0009 & 0.179 \\
\hline & DT & 9 & 5.471 & 0.700 & 0.817 & 0.792 & 0.0343 & 0.143 \\
\hline & XP & 9 & 3.956 & 0.167 & 0.747 & 0.717 & $0.0000 *$ & 0.777 \\
\hline & HK & 12 & 6.792 & 0.533 & 0.853 & 0.837 & $0.0000 *$ & 0.375 \\
\hline & BBW & 12 & 6.250 & 0.433 & 0.840 & 0.821 & $0.0000^{*}$ & 0.484 \\
\hline \multirow[t]{8}{*}{ YC754 } & SD & 9 & 6.818 & 0.633 & 0.853 & 0.837 & 0.0007 & 0.258 \\
\hline & LYG & 12 & 6.383 & 0.300 & 0.843 & 0.826 & $0.0000 *$ & 0.644 \\
\hline & LS & 11 & 5.202 & 0.567 & 0.808 & 0.788 & $0.0000 *$ & 0.298 \\
\hline & $\mathrm{ZS}$ & 10 & 5.263 & 0.500 & 0.810 & 0.788 & $0.0000^{*}$ & 0.383 \\
\hline & DT & 10 & 4.775 & 0.700 & 0.791 & 0.761 & 0.1399 & 0.115 \\
\hline & XP & 11 & 7.059 & 0.433 & 0.858 & 0.842 & $0.0000^{*}$ & 0.495 \\
\hline & HK & 16 & 10.526 & 0.633 & 0.905 & 0.898 & $0.0000 *$ & 0.300 \\
\hline & BBW & 12 & 8.451 & 0.700 & 0.882 & 0.871 & 0.0502 & 0.206 \\
\hline \multirow[t]{8}{*}{ YC764 } & SD & 21 & 15.652 & 0.767 & 0.936 & 0.932 & 0.0058 & 0.181 \\
\hline & LYG & 19 & 12.500 & 0.633 & 0.920 & 0.915 & $0.0000 *$ & 0.312 \\
\hline & LS & 18 & 9.890 & 0.600 & 0.899 & 0.891 & $0.0000^{*}$ & 0.333 \\
\hline & $\mathrm{ZS}$ & 15 & 10.651 & 0.400 & 0.906 & 0.899 & $0.0000 *$ & 0.559 \\
\hline & DT & 18 & 13.043 & 0.667 & 0.923 & 0.918 & $0.0000 *$ & 0.278 \\
\hline & XP & 17 & 12.000 & 0.700 & 0.917 & 0.911 & $0.0000 *$ & 0.236 \\
\hline & HK & 14 & 8.036 & 0.533 & 0.876 & 0.864 & 0.0002 & 0.391 \\
\hline & BBW & 13 & 9.375 & 0.500 & 0.893 & 0.884 & $0.0000 *$ & 0.440 \\
\hline \multirow[t]{8}{*}{ YC792 } & SD & 14 & 8.451 & 0.533 & 0.882 & 0.872 & $0.0000 *$ & 0.395 \\
\hline & LYG & 12 & 7.115 & 0.400 & 0.859 & 0.844 & $0.0000 *$ & 0.535 \\
\hline & LS & 13 & 8.911 & 0.533 & 0.888 & 0.877 & $0.0000^{*}$ & 0.399 \\
\hline & $\mathrm{ZS}$ & 13 & 7.500 & 0.467 & 0.867 & 0.854 & $0.0000^{*}$ & 0.462 \\
\hline & DT & 15 & 9.626 & 0.633 & 0.896 & 0.888 & 0.0003 & 0.293 \\
\hline & XP & 13 & 8.036 & 0.267 & 0.876 & 0.864 & $0.0000 *$ & 0.695 \\
\hline & HK & 16 & 10.778 & 0.700 & 0.907 & 0.900 & 0.0011 & 0.228 \\
\hline & BBW & 16 & 11.538 & 0.700 & 0.913 & 0.907 & 0.0001 & 0.234 \\
\hline \multirow[t]{8}{*}{ All locus } & SD & 14.267 & 9.836 & 0.531 & 0.885 & 0.875 & 0.0038 & 0.405 \\
\hline & LYG & 14.667 & 9.702 & 0.533 & 0.883 & 0.872 & 0.0024 & 0.401 \\
\hline & LS & 15.200 & 10.123 & 0.593 & 0.889 & 0.879 & 0.0139 & 0.334 \\
\hline & ZS & 14.733 & 9.926 & 0.569 & 0.884 & 0.872 & 0.0165 & 0.361 \\
\hline & DT & 14.733 & 10.222 & 0.627 & 0.881 & 0.868 & 0.0441 & 0.290 \\
\hline & $\mathrm{XP}$ & 13.667 & 8.485 & 0.604 & 0.870 & 0.857 & 0.0057 & 0.309 \\
\hline & HK & 13.000 & 8.340 & 0.504 & 0.867 & 0.854 & 0.0004 & $0.426 \mathrm{w}$ \\
\hline & BBW & 13.467 & 8.583 & 0.547 & 0.873 & 0.860 & 0.0430 & 0.379 \\
\hline
\end{tabular}

$\overline{\mathbf{A}}=$ the number of alleles per locus, $\mathbf{A e}=$ the number of effective alleles per locus, $\mathrm{PIC}=$ polymorphism information content, Ho $=$ observed heterozygosity, $\mathrm{He}=$ expected heterozygosity, FIS $=$ the inbreeding coefficient $(*$, significantly value of HWE greater than zero after sequential Bonferroni corrections). 